\title{
Link between Work-Related Prosocial Orientation and Professional Capability of Employees: A Preliminary Exploratory Investigation
}

\author{
Małgorzata Adamska-Chudzińska
}

\begin{abstract}
A B S T R A C T
Objective: The paper explores the link between work-related prosocial orientation of organizations and professional capabilities of employees suggesting that the prosocial orientation impacts the level of professional capability and proactive engagement.

Research Design \& Methods: The article applies three main methods: literature studies, in-depth questionnaire surveys and multi-person method of assessment. The applied sub-measures for both leading constructs were formed and collinearity was tested using linear correlation coefficient.
\end{abstract}

Findings: In prosocial environments psychological predispositions as essential aspects of personality and determinants of human behaviour, activate and stimulate professional activity. The implementation of a prosocial orientation leads to significant growth in professional capability and can influence employees' entrepreneurial behaviour.

Implications \& Recommendations: An important aspect of employee proactive behaviour is building an internal policy based on prosocial mechanisms. Effective stimulation of prosocial and proactive attitudes and actions requires the creation of an environment where activities are realized alongside social values and with respect for individual personal determinants of activity.

Contribution \& Value Added: Considerations and findings presented in the paper contribute to the area of determinants of effective and lasting proactive employee development. The use of the multi-person method can be considered valuable in behavioural research in entrepreneurship

\begin{tabular}{ll}
\hline Article type: & research paper \\
Keywords: & work-related prosocial orientation; professional capability; proactive \\
& employee development
\end{tabular}

JEL codes: L26, M14, 015

Received: 14 December $2014 \quad$ Revised: 2 February $2015 \quad$ Accepted: 16 February 2015

\section{Suggested citation:}

Adamska-Chudzińska, M. (2015). Link between Work-Related Prosocial Orientation and Professional Capability of Employees: A Preliminary Exploratory Investigation. Entrepreneurial Business and Economics Review, 3(1): 107-118, DOI: http://dx.doi.org/10.15678/EBER.2015 .030108 . 


\section{INTRODUCTION}

In current, highly changeable socio-economic conditions, corporate policy constitutes a significant aspect of every company's development. Prosocial policies usually hold regulatory character and are directed towards the stimulation of creative and innovative professional attitudes and behaviours. They influence the activation of company's various resources, including human capital. Bearing in mind that human activity is principally performed in its social context, the policy shaping innovation and creativity environment should take into account prosocial mechanisms regulating human behaviours (Franken, 2007). This paper recognizes the need to root business activities in fundamental social values with respect for human individuality.

The article refers to a stream of widely understood entrepreneurship research with consideration of principles of social responsibility (Koh, Qian \& Wang, 2013). The main aim of the study is to explore potential interdependencies between prosocial activity of an enterprise and entrepreneurship of its employees, hypothesising that implementation of a prosocial orientation positively relates to high level of employee professional capability and their professional behaviours. The presented review of literature and results of own research identify factors that significantly and permanently condition the entrepreneurial attitudes and entrepreneurial intentions, which - as Jiménez-Moreno and Wach (2014) stress - are affected by the social context of external factors such as social norms, role models and perceived behavioural control according to the theory of planned behaviour.

\section{LITERATURE REVIEW}

Brief and Motowidlo's (1986, p. 711) outline that "Prosocial organizational behaviour is behaviour which is: a) performed by a member of an organization; b) directed toward an individual, group, or organization with whom he or she interacts while carrying out his or her organizational role; c) performed with the intention of promoting the welfare of the individual, group, or organisation toward which it is directed." On that basis, Weber, Unterrainer and Höge $(2008$, p. 176) created a concept of work-related prosocial orientation encompassing such indicators as: (i) prosocial work behaviour; (ii) perspective-taking and empathy; (iii) solidarity at work.

The profile of prosocial orientation implemented by an enterprise specifies the character of its influence on the economic outcomes. Contemporary enterprises are increasingly more appreciating the prosocial methods of stimulating entrepreneurship, innovation and proactive attitude and social engagement, as elements of strengthening the firm's market position. Therefore, the problem of prosocial engagement of an enterprise may be grasped twofold. A significant number of enterprises focus on prosocial promotional activity, which consists of adopting external targets, such as sponsoring or corporate philanthropy in order to improve the company image. In this case, the notion of costs that are related to the realization of these promotional social aims, becomes the dominating issue.

A second group of enterprises may choose to adopt a different approach. The prosocial activity, in this case, is perceived as a significant aspect of management 
strategy, sometimes as a tool of developing unique competences or as a source of competitive advantage. The strategic prosocial policies in this case embrace the broadly comprehended needs and expectations of internal and external stakeholders, and which embraces universal social values (e.g. honesty, reliability, responsibility) as criteria for evaluating and assessing actions.

This paper aims at exploring, on both conceptual and empirical level, the potential benefits of a responsible prosocial orientation aimed at establishing an entrepreneurial climate (the environment for entrepreneurship) promoting prosocial and proactive behaviours and social engagement as well as empowerment of employees. Several positive outcomes can be hypothesized a priori. A fundamental one is the individual inclusive treatment of internal and external stakeholders. Second may include an increase of actions directed at corrections, improvements of processes, exploitation of new opportunities. Further long-term benefits may comprise of: reduction of costs and an increase of profitability, an increase in income and profits, including an increase of production, sales and the number of customers (Bąk, Bednarz, Kulawczuk, Rataj, Szcześniak \& Zając, 2007). These potential benefits appear as a result of elevated entrepreneurship and employee effectiveness. When employees' rights and expectations are respected, they can experience important psychological states, connected with the content of the performed work, such as a feeling of significance and authorship of tasks, recognition of competences, consciousness of achievement and work reliability. In prosocial conditions, the effectiveness of processes is elevated thanks to a rational administration of resources and materials, as well as reliable and honest behaviours towards the customers, contractors and local society, who are then more strongly connected with the company through authentic, mutually advantageous cooperation. This fact may also exert some influence on business risk limitation and even greater access to capital.

To explain how the prosocial external and internal environment may cause an increase of entrepreneurship and effectiveness of economic actions (Wach, 2015), and the achievement of the above mentioned benefits, the paper focuses on the concept of professional capability and to social mechanisms influencing and conditioning this capability. Professional capability has been defined for the purpose of this research as internal dispositions (possibility and readiness) of a person, who is competent to fulfil tasks on a given work positions or is prepared for a particular professional role. It is established by a system of physical, mental and social human predispositions, their knowledge resources, skills and motivations that are necessary to perform their work in accordance with expectations of an organization (Adamska-Chudzińska, 2012). Human individual psychological features and qualities play a regulatory role towards the remaining parameters, influencing the final shape of professional capabilities of a human being. The regulatory role of mental predispositions as modelling acts of a person, is presented in numerous works devoted to the concept of personality (Tomaszewski, 1998, pp. 169-170; Przetacznik-Gierowska \& Tyszkowa, 2007, p. 215; Gałdowa, 1999, p. 18; Pervin, 2002, p. 416).

In the prosocial internal environment, where employees are acknowledged as individuals, their needs of affiliations, acceptance and social recognition are fulfilled, the personality determinants of actions, i.e. mental predispositions, become activated. The 
highlighted regulatory role of mental predispositions becomes visible in the fact that they determine and direct human actions (they constitute internal determinants of actions). They are expressed in acts of recognition and evaluation of various elements of situations by individuals. These individual processes of perceiving professional reality (noticing, attentions, memory, imagination, disregard, thinking, abilities, emotional processes and other personality determinants) take place on the basis of possessed knowledge and skills and the remaining characteristics of professional capability. This is the point, where the influence of mental qualities on actions arises from. These individual processes considerably model human behaviours (of a worker, customer, contractor, or other stakeholder), providing it with personal dimension each and every time. They are responsible for use of human capital, scope of their knowledge and skills, thus for the level of their professional capability. The strongly activated mental predispositions on a certain level of knowledge and abilities, enable full exploitation of opportunities brought by human capital and high results of their performance. Therefore, prosocial actions taken up by an enterprise constitute a significant aspect in development of entrepreneurship behaviours, leading to an increase of economic results, i.e. enabling rational decisions and optimal choices. Hence, the corporate prosocial policy creates an environment, which allows subjective determinants of actions, indispensable in achieving a high level of professional capability, which in turn results in the improvement of entrepreneurial attitudes and behaviours.

Studies devoted to prosocial orientation of an enterprise and the influence of prosocial engagement on the level of professional capability and entrepreneurship of employees, and thus economic results, are not numerous. Prosocial character of corporate policy is certainly not among the main researched factors of corporate growth. A certain limitation is posed by considerable complexity and interdisciplinary character of the matter. The problem involves researching the influence of prosocial activity of enterprises on stimulation of psychological regulators of human behaviour and entrepreneurial attitudes and behaviours, and furthermore the reflection of such processes in economic results of enterprises.

Most of the previous research linking prosocial orientation and professional capacities was carried out in the US or Western Europe, therefore the Central European perspective seems to be valuable. Kanter (2009) performed longitudinal studies among highly effective companies for numerous years (among others: PepsiCo, Novartis, IBM, P\&G, Royal DSM, Broad Group, Unilever) in more than 20 countries on different continents. The results of this research suggest a meaningful role of social values in achieving long-standing success within a market (Kanter, 2009). To generate value added, those companies develop structures, where fundamental social values are applied as criteria of decision making. Coexistence of social and economic criteria results in fulfilling the needs of all stakeholders: manufacturing of products, which meet users' expectations; creation of workplaces and development of entrepreneurial attitudes of employees; establishment of strong networks of suppliers and business partners, which serve as a source improvements and innovations, as well as profits (Kanter, 2009). Leaders of the researched companies adopt a prosocial approach as a complementation of economic and financial approach in managing enterprises. Business success of presented enterprises prove that value-based corporate policy is not in opposition to the 
imperative of entrepreneurship and profit generation. These results suggest that corporate development should not be separated from social responsibility (Beard \& Hornik 2011, pp. 88-96).

Studies of Barnett and Salomon (2012) carried over a period of eight years (19982006) on a sample of 1214 biggest enterprises in the world, suggest the existence of a Ushape correlation between social activity and financial results in a long-term perspective. The relationship was measuring the return on assets and the return of equity of enterprises.

The entrepreneurial attitudes, as those desired by companies in contemporary changeable conditions, that require deep engagement, and continuous creation of new solutions are the subject of research realized by Corporate Leadership Council in 2008. The study results suggest that an entrepreneurial employee gives $57 \%$ more effort than the one, who was not identified with that feature. A $10 \%$ growth of engagement causes $6 \%$ increase of contribution at work, which is reflected in $2 \%$ increase of the generated results (Chair, 2014).

In Poland, the Forum of Responsible Business (Forum Odpowiedzialnego Biznesu Ranking (SR) - a multi-criteria rank of responsible companies -is published annually. This initiative systematically perfected, results in an expanding group (more than 60 per year) of enterprises that face high social and ecologic requirements, which lead to an increase of engagement of employees and contractors, and therefore to acquisition of knowledge that allows to strengthen their economic position within a market (Gasparski, 2012). These studies, together with other analyses of prosocial corporate policies (Kuraszko \& Augustyniak, 2009) demonstrate an increasing scope of social responsibility among Polish businesses. These studies broaden the platform of competition with social responsibility aspects, thanks to which all market partners gain benefits. The discussed studies do not analyse, however, the influence of prosocial orientation of an enterprise on indirect parameters of economic growth, such as professional capability and entrepreneurial behaviours of employees.

The prosocial aspect of the business strategy and behaviour was the subject of research conducted at the Cracow University of Economics in the years 2008-2010 ${ }^{1}$. The obtained research results, while requiring further verification on a greater group of companies, embrace significant premises that point to a relationship between prosocial activity of enterprises and an increase of professional capability and entrepreneurial behaviours of workers. Some selected results are presented and elaborated in this article.

\section{MATERIAL AND METHODS}

The results presented are selected elements of a larger research project carried out by the author that relate to interdependencies between the degree of prosocial engagement of an enterprise and the level of activation of employees 'professional capability. Diagnose of this relationship addresses the driving question of the study: to

\footnotetext{
${ }^{1}$ The studies conducted at the Department of Psychology and Didactics at the Cracow University of Economics as Own Research Project no. 67/KPID/2/08/W/075.
} 
what extent does the scope of autonomy, proactivity and innovativeness, as important sub-constructs of entrepreneurship behaviour, increase in prosocial conditions? The studies were of exemplifying character, and they were carried out in two stages, in 2008 and 2010, in an enterprise of leading position on the market in its branch, with an opinion of having a high level of social responsibility.

The goal of the study required to divide the research into three parts: (i) analysis and evaluation of prosocial orientation in the analysed enterprise; (ii) evaluation of the level of professional capability of the workers employed in it; (iii) determination if and to what extent the prosocial orientation coexists and impacts the level of professional capability of employees.

The prosocial orientation of a firm was measured using four submeasures and four different questionnaires. The sub-measures of prosocial orientation, selected for the study, embraced the following aspects:

1. Reliability of basic operations of the organization (quality assurance).

2. Improvement of operations through elimination of losses (rationality of managing organizational resources).

3. Axiological reference of the managers (social valuation and assessment of tasks).

4. Individual treatment of employees (experiencing personal participation in work situations, significance and authorship of actions).

These sub-measures of prosocial orientation constitute basic social dimensions of each organization, and they co-determine its prosocial orientation.

In turn, the level of employees' professional capability was assessed on the basis of the following sub-measures:

1. physical qualipties,

2. mental predispositions,

3. social competences,

4. professional knowledge,

5. content-related skills,

6. work motivation.

According to the concept of the regulation of human behaviours (Ratajczak, 2007), the above quoted determinants represent essential characteristics of professional capability.

To verify the interdependence between indications of prosocial orientation of an enterprise, and the level of professional capability of the employees, appropriate research tools were prepared. A survey technique and four scales were exploited to examine the prosocial orientation. The evaluation of professional capability encompassed a multi-person method employee assessment, and a simplified evaluation sheet of professional capability of employees in relation to requirements of a certain type of job was prepared. It took into consideration the sub-measures of professional capability and a general evaluation of professional potential of an employee.

The level of prosocial orientation in the researched enterprise was determined with application of a special procedure of standardization of measures obtained from the four questionnaires and calculation of aggregated indicators. Evaluation of professional capability was formulated on the basis of opinions of competent judges (operational managers, managers of higher level and co-workers). 
In order to recognize the relationships between aggregated prosocial orientation indicators and professional capability of employees indicator, both within the groups of those measures, and between them, coefficient of linear correlation was applied.

Analysis of the obtained results was conducted according to the subsequent stages of research with reference to selected psychological and sociological theoretical concepts. To some extent, it allowed to overcome the limitations of the correlation method, and provide the research with, maybe not exploration, but rather a verification directed at identification of the researched interdependences. Furthermore, the analysis was complimented by analysis of documentation related to socio-economic operation of the examined enterprise.

Two variables investigated in the study were measured by using two different techniques. The questionnaire was used for the first variable (prosocial orientation). The basic responding group included 151 respondents from one firm. They were asked to answer 4 different questionnaires (so altogether there were 604 questionnaires collected from 151 respondents). The multi-person method of employee's assessment was applied to measure professional capability. For the second phase only 40 employees were selected out of 151 of all employees who replied the questionnaire. They were evaluated by 10 so called judges (each employee was evaluated by three judges including a top manager, a direct supervisor, and a co-worker).During the empirical studies, in-depth 120 opinions about professional capability of 40 employees were gathered $(40 \times 3)^{2}$.

\section{RESULTS AND DISCUSSION}

\section{Evaluation of Prosocial Orientation}

The aggregated variable of prosocial orientation was constructed of four sub-variables (mentioned above in the text). Research results referring to the level of intensity of prosocial aspects in business activity of all investigated employees of the selected enterprise $(n=151)$ revealed a high social engagement indicator (reaching 0.6 on a 0-1 scale). The dimension corporate prosocial orientation was expressed in:

- combining economic effectiveness with care for stakeholders needs and expectations (high significance to the professional capability of the employed, as the main determinant of quality value added),

- improving economic activity through raising rationality of managing organizational resources (responsibility for resources and interests of the organization including the employees, maintaining respect and recognition for them as a significant source of cognition and creativity),

- combining management effectiveness with axiologically directed attitudes of managers (social valuation and assessment of economic actions, their course and effects),

\footnotetext{
${ }^{2} \mathrm{~A}$ full characteristic of methodological assumptions and data obtained in the presented research, together with the graphic presentation, are included in chapters 4 and 5 of the publication of Adamska-Chudzińska (2012).
} 
- individual treatment of organization members (full personal participation in work situations, significance and authorship of their actions).

Relationship between the researched types of actions (four sub-measures of prosocial orientation) and a general state of prosocial orientation was statistically confirmed (linear correlation). Taking actions in the four separate areas was accompanied by an increase of overall prosocial orientation intensity in an enterprise. This confirmed the introduced sub-scales, as reliable for examining the prosocial orientation of an enterprise.

The obtained results also confirmed a dominating role of individual treatment of employees in shaping prosocial orientation $(0.721, p<0.05)$.A statistically significant difference was noted between individual treatment of employees and other areas of prosocial orientation. It suggests that the intensification of individual treatment of employees, impacts the intensity of the remaining areas of prosocial corporate orientation.

\section{Evaluation of Professional Capability}

The average assessment of the professional capability potential of all employees $(n=40)$ of the investigated enterprise amounted to 4.25 on a $1-5$ scale. Between $90 \%$ and $95 \%$ of all six sub-measures of the professional capability of the evaluated employees were high and very high.

The analysis of correlations between sub-measures of professional capability established that mental predispositions are correlated with all analysed parameters. It suggests that a higher level of stimulation of mental qualities and characteristics is accompanied by higher physical mobilization of the body, better communication abilities, fuller application of knowledge and skills, as well as an increase in work motivation. The essential role played by mental predispositions in effective realization of professional tasks has been confirmed on the sample. The formulated conclusions are in line with psychological personality concepts (Tomaszewski, 1998, pp. 169-170; Przetacznik-Gierowska \& Tyszkowa, 2007, p. 215; Gałdowa, 1999, p. 18; Pervvin, 2002, p. 416), according to which compliance and balance of mental predisposition determines the level of maturity individuals and the activation of personal resources, such as skills and knowledge. This occurs through:

- cognitive processes, deciding about reflection and analysis of the surrounding reality,

- intellectual processes and special skills, which determine the level professional excellence,

- emotional processes, being responsible for mental self-regulations and the ability to act rationally,

- features of character, aligning human actions with the personal values system,

- temperament features, conditioning the dynamics of behaviours, along with motivation.

\section{Link between Prosocial Orientation and Professional Capability}

The statistical calculations of linear correlation coefficient identified a statistically significant interdependence between the aggregated intensity of prosocial orientation and professional capability within the mental predispositions (0.709), physical qualities 
(0.527) and social competences of employees (0.491). It implies that in the researched company, the growth of intensity of prosocial orientation impacts three aspects of professional capabilities:

i. intensification of physical possibilities of action,

ii. enhancement of mental abilities of perceiving and valuating work situations,

iii. attitude towards development of constructive professional relationships.

In prosocial conditions, there is a possibility to expect intensification of physiopsycho-social features and qualities of employees, and as a consequence, their stronger internal commitment to effectiveness.

The relationship between individual employee treatment and mental predispositions suggests that treating employees with dignity, respecting their rights and providing them with proper autonomy and authorship of actions results in higher mental readiness for effective dealing with professional challenges.

According to the obtained results, there is a need to consider the fact that individual employee treatment is not only one sub-dimension of prosocial orientation, but also a basic condition of prosocial actions in other dimensions. Therefore, it may be expected that the fulfilment of this condition may cause an increase in: (a) stakeholder value added, (b) general work excellence and eliminating losses, (c) social valuation and assessment of actions.

In turn, "mental predispositions", according to the results, play a regulatory role towards all remaining determinants of professional capability. They are responsible for activating employee mental processes, grasping various aspects of situations, intensification of acts and creation of their new dimensions.

An important contribution of the analysis lays in identifying factors that condition the prosocial orientation of the enterprise, and factors that model professional capability. On a very limited scope and single case sample the study identified that a high intensity of prosocial corporate orientation is likely to activate the professional capability of employees. The interdependence between mental predispositions and prosocial orientation was recorded in the research enterprise not only in the area of individual treatment of the employees, but also in the area of reliable realization of tasks. However, further research is still needed. Quantitative studies covering numerous companies, may provide further insight into the subject.

\section{CONCLUSIONS}

The application of prosocial corporate orientation for triggering and stimulating creative and innovative activity of employees may be a significant aspect of creating an effective internal entrepreneurship policy. The presented finding simply that the prosocial corporate orientation may lead to the achievement of superior economic results through an increase of employee professional capability. The presented data emphasizes the relative durability of these effects and long-term strengthening of market position, thanks to prosocial regulators of human behaviours.

Since individual superior performance becomes strongly active in prosocial conditions, it is significant to build prosocial orientation in all areas of enterprises' operation. This process requires the economic activity to incorporate fundamental social 
values as criteria of evaluating and assessing actions, and promoting an ethical profile of professional relationships. The phenomenon of individual dignity is exposed by the fact that it is both a manifestation, and a basic condition of taking prosocial actions.

Findings of the study strongly emphasize the aspect of individual treatment of employees as a key demotion of prosocial orientation and key determinant of professional capability. Respect for human individuality in organizational contexts is demonstrated on two levels. The elementary level is connected with respect for the dignity of the employees, their rights and high standards of work. A higher level of individual employee treatment consists of providing people with an adequate scope of autonomy and work responsibility. That raises employee's awareness of personal influence on the course of events, triggers a feeling of achievement and encourages taking responsibility for new solutions which is specific for entrepreneurial attitudes.

These mechanisms play a huge role in all empowering aspects of management, such as sharing power, encouraging employees to take part in decision making (Peters \& Waterman, 2004), application of open and clear information policy (Aggarwal \& Simkins, 2001, pp. 5-13); defining employee tasks in the context of the mission and strategies of an enterprise (Kidwell \& Scherer, 2001, pp. 113-124); concluding a psychological contract between an employee and an employer that reflects social values.

An individual approach to people in professional relationships leads to an increase in professional capability, which may result in the development of entrepreneurial attitudes and behaviours among employees.

\section{REFERENCES}

Adamska-Chudzińska, M. (2012). Uwarunkowania sprawności zawodowej człowieka w organizacji. Aspekt prospołeczny. Kraków: Wydawnictwo Uniwersytetu Ekonomicznego w Krakowie.

Aggarwal, R., \& Simkins, B. (2001). Open-book management-Optimizing human capital. Business Horizons, 44(5), 5-13.

Barnett, M.L., \& Salomon, R.M. (2012). Does it pay to be really good? Addressing the shape of the relationship between social and financial performance. Strategic Management Journal, 33(11), 1304-1320. DOI: 10.1002/smj.1980.

Bąk, M., Bednarz, P., Kulawczuk, P., Rataj, R., Szcześniak, A., \& Zając, P. (2007). Analiza korzyści ekonomicznych ze stosowania zasad społecznej odpowiedzialności biznesu (CSR) w polskich przedsiębiorstwach. Streszczenie i wnioski. In P. Kulawczuk, \& A. Poszewiecki (Eds.), Wpływ społecznej odpowiedzialności biznesu i etyki biznesu na zarzq̨dzanie przedsiębiorstwami (pp. 55-112). Warszawa: IBnDiPP, EQUAL.

Beard, A., \& Hornik, R. (2011). It's Hard to Be Good. But it's worth it. Here are five companies whose success is built on responsible business practices, Harvard Business Review, November, 88-96.

Brief, A.P., \& Motowidlo, S.J. (1986). Prosocial organizational behaviors. Academy of Management Review, 11, 710-725.

Chabior, J. (2014). [online] Potencjał biznesowy zaangażowanych pracowników. HR Mobilny 14.08.2014. Retrieved on August 4, 2014 from: <http://hrmobilny.pl/artykuly-hr/ potencjal-biznesowy-zaangazowanych-pracownikow/page-4>.

Franken, R.E. (2007). Human Motivation. Belmont, CA: Thomson Wadsworth. 
Gałdowa, A. (1999). Klasyczne i współczesne koncepcje osobowości, Tom 1. Kraków: Wydawnictwo Uniwersytetu Jagiellońskiego.

Gasparski, W. (Ed.). (2012). Biznes, etyka, odpowiedzialność. Warszawa: PWN.

Jiménez-Moreno, J.J., \& Wach, K. (2014). The entrepreneurial profile of students participating in the academic entrepreneurship course: pilot study results. Horyzonty Wychowania, 13(26), 121-144.

Kanter, M.E. (2009). SuperCorp: How Vanguard Companies Create Innovation, Profits, Growth, and Social Good. New York: Crown Business.

Kidwell, R.E., \& Scherer, P.M. (2001). Layoffs and their ethical implications under scientific management, quality management and open-book management. Journal of Business Ethics, 29(1/2), 113-124.

Koh, P.-S., Qian, C., \& Wang, W. (2014). Firm litigation risk and the insurance value of corporate social performance. Strategic Management Journal, 35(10), 1464-1482.

Kuraszko, I., \& Augustyniak Sz. (2009). 15 polskich przykładów społecznej odpowiedzialności biznesu. Warszawa: Forum Odpowiedzialnego Biznesu.

Pervin, L.A. (2002). Psychologia osobowości. Gdańsk: GWP.

Peters, T.J., \& Waterman, R.H. (2004). In Search of Excellence: Lessons from America's Best-Run Companies. Boston: Harper Business.

Przetacznik-Gierowska, M., \& Tyszkowa, M. (2007). Psychologia rozwoju człowieka. Zagadnienia ogólne, Tom 1. Warszawa: PWN.

Ratajczak, Z. (2007). Psychologia pracy i organizacji. Warszawa: PWN.

Tomaszewski, T. (1998). Główne idee współczesnej psychologii. Warszawa: Żak.

Wach, K. (2015), Impact of Cultural and Social Norms on Entrepreneurship in the EU: Cross-Country Evidence based on GEM Survey Results. Zarzqdzanie $w$ Kulturze, 16(1), 15-29. DOI: 10.4467/20843976ZK.15.002.3037

Weber, W.G., Unterrainer, Ch., \& Höge, Th. (2008). Sociomoral atmosphere and prosocial and democratic value orientations in enterprises with different levels of structurally anchored participation. Zeitschrift für Personalforschung, 22(2), 171-194. 


\section{Author}

\section{Małgorzata Adamska-Chudzińska}

Habilitated doctor (dr hab.) of Management Science at Cracow University of Economics at the Department of Psychology and Didactics. Her research interests include psycho-social determinants of professional capability of employees and the quality of economic education in high school.

\section{Correspondence to:}

Dr hab. Małgorzata Adamska-Chudzińska

Cracow University of Economics

Faculty of Economics and International Relations

Department of Psychology and Didactics

ul. Rakowicka 27, 31-510 Kraków, Poland

achm@uek.krakow.pl

\section{Financial Disclosure}

The paper includes selected findings from author's own research No. 67/KPiD/2/08/W/075 financed by the Cracow University of Economics conducted by the author of this article in the years 2008-2010.

\section{Copyright and License}

This article is published under the terms of the Creative Commons Attribution - NonCommercial - NoDerivs (CC BY-NC-ND 3.0) License http://creativecommons.org/licenses/by-nc-nd/3.0/ 